\title{
A New Method for the Preparation and Some Properties of Staphylococcal Delta-haemolysin
}

\author{
By N. G. HEATLEY \\ Sir William Dunn School of Pathology, University of Oxford, Oxford
}

(Accepted for publication 3 I August 197I)

SUMMARY

Staphylococcal delta-haemolysin is soluble and stable in chloroform + methanol $(2: \mathrm{I}, \mathrm{V} / \mathrm{v})$. It distributes mainly in the lower phase of chloroform + methanol + water (10:5:3, by vol.) under neutral conditions, but almost entirely in the upper phase in the presence of acid, and was purified by cyclic transfer from one phase to the other. The final product gave a single peak on ultracentrifugation but was polydisperse, and on polyacrylamide gel showed a second faint band. It is very soluble in water being a simple protein of moderate molecular weight containing no lipid and, at most, only traces of phosphorus and carbohydrate. It does not contain tyrosine, arginine, proline or cystine.

Though stable over a wide range of $\mathrm{pH}$, in dilute solution it is rapidly adsorbed to glass and other surfaces, which makes accurate assay difficult. Haemolytic activity is low; I mg. contains 250 to 300 Haemolytic Units (HU) per ml.

\section{INTRODUCTION}

The literature on staphylococcal delta-haemolysin, first reported by Williams \& Harper (I947), has been summarized recently by Hallander (I968), Wiseman (1970) and Kreger, Kim, Zaboretzky \& Bernheimer (197I). The work reported here arose from an attempt, started some years ago, to prepare the crystalline material as described by Yoshida (1963).

Initially the lysin was prepared from Staphylococcus aureus FOGGIE, as used by Yoshida (1963). This, however, formed beta-lysin also, which to some extent accompanied the deltalysin during purification and produced unpredictable and large assay errors because (i) the delta- and beta-lysin were synergistic and (ii) the potency of the delta-lysin-beta-lysin system was dependent on concentration of $\mathrm{Ca}^{2+}, \mathrm{Mg}^{2}+$ and $\mathrm{Mn}^{2+}$. Thereafter only $S$. aureus NEWMAN was used which does not produce beta-lysin-at least, not in the substrain used here.

\section{METHODS}

Organism and medium. As Staphylococcus aureus NEwMAN lost the ability to form deltalysin when maintained on agar an actively producing strain, known as ' $186 \mathrm{x}$ ', was reselected and stored in freeze-dried form. It was grown on the medium of Gladstone \& van Heyningen (1957) which contains (per 1.): casein acid hydrolysate (Oxoid), 20 g.; yeast diffusate, $200 \mathrm{ml}$.; sodium lactate, $70 \%$ syrup (British Drug Houses Ltd, Poole, Dorset), $14 \mathrm{ml}$; sodium $\beta$-glycerophosphate, $20 \mathrm{~g}$.; $\mathrm{MgSO}_{4} \cdot 7 \mathrm{H}_{2} \mathrm{O}, 20 \mathrm{mg}$.; $\mathrm{MnSO}_{4} \cdot 4 \mathrm{H}_{2} \mathrm{O}$, $10 \mathrm{mg}$.; $\mathrm{KH}_{2} \mathrm{PO}_{4}$, $0.40 \mathrm{~g}$.; $\mathrm{Na}_{2} \mathrm{HPO}_{4}$. $\mathrm{I}_{2} \mathrm{H}_{2} \mathrm{O}, 6.25 \mathrm{~g}$.; and $2 \mathrm{ml}$. of a solution containing $0.32 \%$ (w/v) $\mathrm{FeSO}_{4}$. ${ }_{7} \mathrm{H}_{2} \mathrm{O}+0.32 \%(\mathrm{w} / \mathrm{v})$ citric acid. The yeast diffusate was prepared by dialysing $280 \mathrm{~g}$. yeast extract ('Yeastex', Trent Yeast Co. Ltd, Burton-on-Trent, Staffordshire) in $200 \mathrm{ml}$. of water against $1800 \mathrm{ml}$. water in the cold with constant rocking, usually for 16 to $20 \mathrm{~h}$.

Cultivation of the organism and extraction of delta-lysin. T-tubes (van Heyningen \& Glad- 
stone, 1953), each half filled with 35 to $40 \mathrm{ml}$. of the medium, were inoculated with $\mathrm{I} \mathrm{ml}$. of a log-phase broth culture and rocked at 55 cycles/min. in a water bath at $38^{\circ}$ for 16 to $20 \mathrm{~h}$. For turbidity measurements, clumps of bacteria adhering to the tubes were dislodged with a magnet and its follower. Cultures were centrifuged at $2000 \mathrm{~g}$ for $30 \mathrm{~min}$. and the supernatant fluid kept at $60^{\circ}$ for $\mathrm{I} h$. to kill residual bacteria and destroy any alpha-lysin. The cooled fluid, with a slight precipitate, was placed in cellophane sacs and buried in solid $\left(\mathrm{NH}_{4}\right)_{2} \mathrm{SO}_{4}$ (A. M. Woodin, personal communication) for a few hours. The lysin precipitate was collected on an Oxoid membrane and dried. A yield of 0.4 to $0.8 \mathrm{~g}$. of lysin/l. of culture fluid was obtained with an activity of 10 to $40 \mathrm{HU} / \mathrm{mg}$.

About $200 \mathrm{mg}$. of dried precipitate were extracted three times with $15 \mathrm{ml}$. chloroform + methanol $(2: \mathrm{I}, \mathrm{v} / \mathrm{v})$ in a homogenizer fitted with a Teflon pestle, the tube being centrifuged after each extraction. The combined extracts were shaken for I min. with one-fifth of their volume $0.05 \mathrm{M}$-phosphate buffer, $\mathrm{pH} 6.8$, containing $0.05 \mathrm{M}-\mathrm{NaCl}$. The mixture was centrifuged if necessary, the lower phase removed, and the top phase extracted once or more with fresh 'Folch lower layer', i.e. the lower layer in the system chloroform + methanol + water (10:5:3, by vol.) (Folch, Lees \& Sloane-Stanley, I957). The spent pigmented top layer was discarded. The pooled lower layers were then shaken with fresh 'Folch top layer' (i.e. the top layer in the system just mentioned), 5 M-phosphoric acid being added until the final top layer became reddish orange with thymol blue on a spotting tile. The separated top layer, containing almost all the lysin, was neutralized and the lysin was extracted back into fresh 'Folch lower layer'. This was evaporated, the residue was taken up in 10 to $20 \mathrm{ml}$. of chloroform + methanol $(2: \mathrm{I}, \mathrm{v} / \mathrm{v})$ and the lysin was precipitated by adding ten vol. of acetone, centrifuging after it had flocculated, washing the precipitate with acetone (in which it is insoluble) and drying briefly. It was stored at $4^{\circ}$ without desiccant. It could be equally well precipitated from a concentrated top layer by 10 vol. of acetone.

Assay of delta-lysin. This was based on the method of Yoshida (1963), with phosphatebuffered saline (PBS) of the following composition (g./1.): $\mathrm{NaCl}, 5 \cdot 86 ; \mathrm{Na}_{2} \mathrm{HPO}_{4} \cdot \mathrm{I}_{2} \mathrm{H}_{2} \mathrm{O}$, $8.96 ; \mathrm{KH}_{2} \mathrm{PO}_{4}, 3.40$. (The buffer mentioned by Yoshida-presumably misprinted - is hypotonic, causing spontaneous lysis of red blood corpuscles.) Blood ( $1 \cdot 0 \mathrm{ml}$.), always from the same donor, was mixed with Io $\mathrm{ml}$. of citrate saline (I vol. $3.8 \%(\mathrm{w} / \mathrm{v}$ ) sodium citrate + 9 vol. $0.9 \%(w / v) ~ N a C l)$, centrifuged, and the corpuscles washed twice with I I ml. saline and finally resuspended in PBS to $25^{\circ} 0 \mathrm{ml}$. For an assay, $0.5 \mathrm{ml}$. of this suspension +lysin + PBS to $1.00 \mathrm{ml}$. were shaken for $15 \mathrm{~min}$. in a water bath at $37^{\circ}$. The tubes, after cooling, were centrifuged, the supernatant was diluted in 5 vol. of $0.1 \% \mathrm{Na}_{2} \mathrm{CO}_{3}$ and the percent haemolysis estimated by comparison, either visually or at $54 \mathrm{I} \mathrm{nm}$. in a spectrophotometer, with a fully haemolysed solution as control. Such a control has $E_{1 \mathrm{~cm},}=$ about 0.42 . (As the absorption peak is narrow, the $\lambda_{\max }$ should be checked, otherwise large errors result.) Because of rapid adsorption of lysin to the assay tubes these were first all charged with $0.5 \mathrm{ml}$. red corpuscle suspension + the calculated volume of PBS. The lysin was then added, in as small a volume as possible, and the tube was incubated immediately.

For lysin in solutions containing chloroform or methanol, known volumes were evaporated under reduced pressure and the residues twirled with a bent glass thread with $0.45 \mathrm{ml}$. $0.02 \mathrm{M}-\mathrm{NaOH}$, then mixed with $0.05 \mathrm{ml}$. of a mixture designed to bring the final $\mathrm{pH}$ and osmolarity to that of the PBS.

Suspensions of lysin were diluted in alkali and neutralized as above just before assay; the suspended solid sometimes reformed, but was usually more finely divided.

Assay tubes immediately after use were rinsed in water and soaked in 0.05 to $0 . \mathrm{I} \mathrm{M}-\mathrm{NaOH}$ for an hour or more, then rinsed well and dried in the oven. 
Standards; units. By definition I Haemolytic Unit (HU) is that amount of lysin which gives $50 \%$ haemolysis under the conditions described. As there was considerable variation from assay to assay external standards were made. These consisted of small tubes, each containing the dried residue from an accurately measured volume of a chloroform + methanol solution, and were stored at $4^{\circ}$ in a closed jar, with or without silica gel, where they appeared to retain their activity indefinitely. The contents of a tube were dissolved in $0.45 \mathrm{ml}$. dilute alkali by twirling with a bent glass thread, then neutralized as above and a fixed volume assayed. After several assays a mean HU content per tube was calculated and applied retrospectively and to future assays.

Relation between concentration of lysin and percentage haemolysis. Owing to adsorption of lysin to glass, etc., it is not easy to determine this relation precisely but it appeared to be linear within the range 10 to $60 \%$.

Staining of polyacrylamide gels and agar-slide electrophoresis patterns. Naphthalene Black I $2 B$ and Coomassie Brilliant Blue were both used. Batches of the latter labelled ' $R$ ' and 'RL' (both Michrome no. I I37. from Edward Gurr Ltd, London, S.W. 14) gave excellent results with the procedure of Chrambach, Reisfeld, Wyckoff \& Zacchari (1967), whereas that labelled 'RL' (Michrome no. IOO) from the same supplier did not stain the lysin.

Amino acid analysis. After hydrolysis of lysin at $110^{\circ}$ for $16 \mathrm{~h}$. in a sealed tube with $6 \mathrm{M}-$ $\mathrm{HCl}$, an analysis of the amino acids was carried out on an EEL Amino Acid Analyser (Evans Electroselenium Ltd, Halstead, Essex). Table I. The effect of added DL-tryptophan on pH, cell mass,
and yield of delta-lysin

Five T-tubes were set up for each determination and the contents pooled; total volume about $180 \mathrm{ml}$. The apparent lower content of lysin in ammonium sulphate precipitate compared with that of heated crude culture supernatant is at least partly due to 'enhancing factor' in the latter (see text).

\begin{tabular}{|c|c|c|c|c|c|c|c|c|}
\hline \multirow{2}{*}{$\begin{array}{l}\text { Final concentration } \\
\text { of added tryptophan } \\
\text { (mM) }\end{array}$} & \multicolumn{2}{|c|}{0} & \multicolumn{2}{|c|}{0.73} & \multicolumn{2}{|c|}{$I \cdot 46$} & \multicolumn{2}{|c|}{$2 \cdot 20$} \\
\hline & Expt I & Expt 2 & Expt I & Expt 2 & Expt I & Expt 2 & Expt I & Expt 2 \\
\hline Final pH of culture & $6 \cdot 95$ & $7 \cdot 1$ & $6 \cdot 95$ & $7 \cdot 1$ & $6 \cdot 95$ & $7 \cdot 1$ & $6 \cdot 95$ & $7 \cdot 1$ \\
\hline $\begin{array}{l}\text { Bacterial dry wt } \\
\text { (mg./ml.) }\end{array}$ & 3.0 & $4^{\cdot I}$ & $2 \cdot 95$ & $4 \cdot 4$ & $3 \cdot 15$ & $4 \cdot 7$ & $3 \cdot 20$ & $4 \cdot 4$ \\
\hline \multicolumn{9}{|l|}{ Total HU } \\
\hline $\begin{array}{l}\text { In heated crude } \\
\text { culture supernatan }\end{array}$ & 4,680 & 5,400 & 9,700 & 9,850 & 12,150 & I 1,600 & 10,600 & I 1,300 \\
\hline $\begin{array}{c}\text { In }\left(\mathrm{NH}_{4}\right)_{2} \mathrm{SO}_{4} \\
\text { precipitate }\end{array}$ & 1,600 & 1,600 & 5,400 & 6,320 & 6,400 & 5,650 & 5,100 & 5,510 \\
\hline
\end{tabular}

\section{RESULTS}

Production experiments. Delta-lysin is produced wholly extracellularly since no more was freed by washing the bacteria or incubating them in water or PBS. They did, however, yield an unstable haemolysin on extraction by dilute alkali, confirming the previous work of Plommet \& Bouillanne (I966).

In several experiments changes in the composition of the medium failed to increase the yield. Towards the end of the work, however, when there was evidence that the lysin contained tryptophan in fairly large amounts, added tryptophan was found to increase the yield three- to fourfold (Table I). This was confirmed with two different batches of medium but in two other batches added tryptophan had little effect, the yield being initially high. There was no correlation between yield of lysin and final $\mathrm{pH}$ of the culture or amount of growth, as measured turbidimetrically. 


\section{Observations related to the assay of delta-lysin}

Some factors affecting the accuracy and repeatability of the assay are described below, but, irregular results are still frequently obtained.

Enhancing factors. The apparent potency of a preparation was higher when dissolved in the modified CCY medium than in PBS and was caused solely by the casein acid hydrolysate (Fig. I). Ash of this hydrolysate, or equivalent amounts of asparagine, glutamate, or glycine, or the synthetic tissue culture medium 'I 99 ' of Morgan, Morton \& Parker (I950) showed no effect. Its action was primarily on the red blood corpuscles which, when incubated with

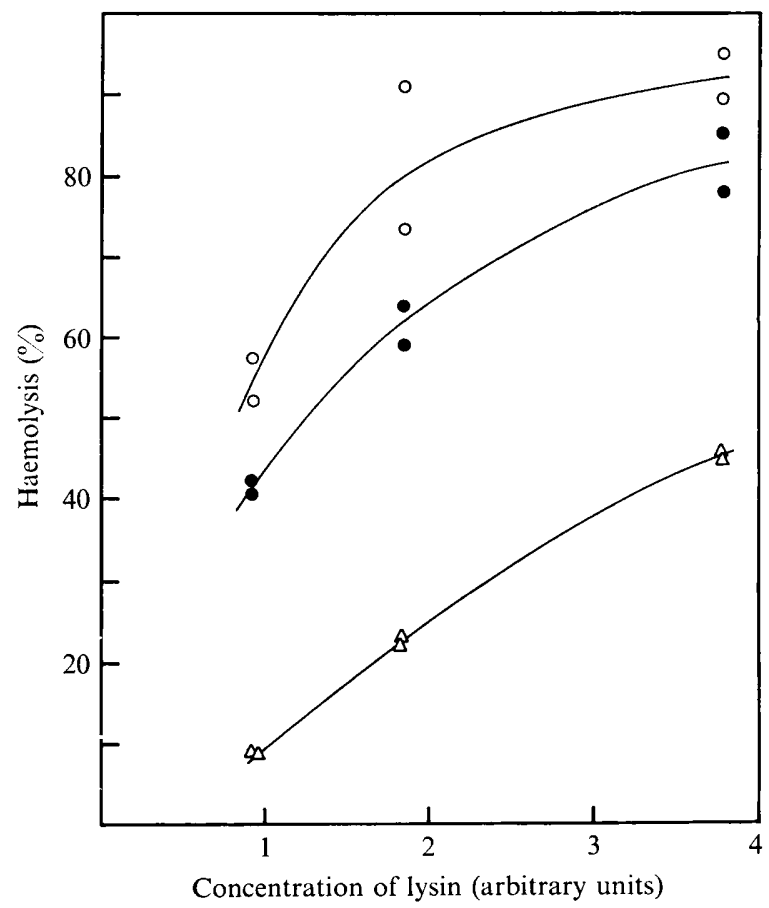

Fig. I. The effect of Oxoid casein acid hydrolysate on the amount of haemolysis caused by delta lysin. No casein hydrolysate, $-\triangle-\triangle-$; casein hydrolysate at $0.9 \mathrm{mg} . / \mathrm{ml}$., $\longrightarrow-$; and at $3.4 \mathrm{mg} . / \mathrm{ml}$., $-\mathrm{O}-\mathrm{O}-$.

a $0.1 \%$ solution of the hydrolysate, centrifuged and resuspended in fresh PBS, gave the same enhanced haemolysis as when the casein hydrolysate was present during the assay. The increased sensitivity of the red corpuscles to the lysin was not accompanied by an increase in osmotic fragility. The sensitizing effect was rapid, for it occurred when the digest was added to the assay mixture immediately before incubation. It was partly lost on autoclaving (10 min., I5 lb./sq. in.). Two batches of casein acid hydrolysate (Oxoid), one of BactoCasamino acids (Difco) (also an acid hydrolysate), and one of Bacto-Casitone (Difco) (a pancreatic casein digest) all showed the effect, as did peptone (Evans Medical Ltd, Liverpool). Protamine (ex herring; Koch-Light Ltd, Colnbrook, Buckinghamshire) showed a slight effect, but Neopeptone (Difco) and crystalline egg lysozyme (Armour Chemicals Ltd, London) showed none.

The medium used for the preparation of delta-lysin contains casein digest, but how much 
of its enhancing effect remains after cells have grown in it is not easy to determine. That some remained is suggested by the apparent large loss which accompanied the first $\left(\mathrm{NH}_{4}\right)_{2} \mathrm{SO}_{4}$ precipitation (e.g. Table I), since further successive precipitations gave an average of only $9 \%$ loss per precipitation.

\section{Disappearance of lysin in dilute solution}

Dilute solutions of lysin (about $2 \mathrm{HU} / \mathrm{ml}$.) adsorbed quickly and strongly to glass, even to glass made water-repellent in various ways. It also adsorbed on polypropylene. This adsorption was not prevented by bovine serum albumin or gelatine, whether used to pretreat assay tubes or whether actually present during the assay.

Table 2. Partition coefficients and recoveries in the system chloroform + methanol + water (10:5:3, by vol.) at room temperature The lysin - about $62 \mathrm{HU}$ of the same sample throughout - was made up in $0.50 \mathrm{ml}$. of water at the
pH and with the concentration of $\mathrm{NaCl}$ (if any) given in columns I and 2 . Then $2.5 \mathrm{ml}$. of chloro-
form + methanol (2:I) were added, the tubes were shaken, centrifuged, and the two phases assayed.
The mean overall recovery from all experiments was $76.6 \%$.

\begin{tabular}{|c|c|c|c|}
\hline $\mathrm{pH}^{*}$ & $\begin{array}{c}\text { Conc. of } \\
\mathrm{NaCl}(\mathrm{M})^{*}\end{array}$ & $\begin{array}{l}\text { Partition } \\
\text { coefficient }\end{array}$ & $\begin{array}{c}\text { Recovery } \\
(\%)\end{array}$ \\
\hline$<2.5$ & 0 & I $2 \cdot I$ & 79 \\
\hline 2.5 & 0 & $\begin{array}{l}27 \\
15 \\
19 \cdot 8 \\
12 \\
12 \\
16 \cdot 5 \\
11 \cdot 4 \\
17 \\
14 \cdot 1\end{array}$ & $\begin{array}{r}109 \\
69 \\
56 \\
103 \\
111 \\
106 \\
75 \\
91 \\
33\end{array}$ \\
\hline 7 & 0 & $I \cdot I$ & 77 \\
\hline 10.5 & 0 & 0.16 & 62 \\
\hline $2 \cdot 5$ & 0.1 & $\begin{array}{l}\mathrm{I} \cdot \mathrm{I} \\
4 \cdot 9 \\
7 \cdot 5 \\
3 \cdot \mathrm{I}\end{array}$ & $\begin{array}{l}75 \\
90 \\
65 \\
71\end{array}$ \\
\hline 3.5 & 0.1 & 0.83 & 54 \\
\hline $7 \cdot 0$ & $0 \cdot I$ & 0.36 & 73 \\
\hline 7.0 & 0.35 & 0.34 & 76 \\
\hline 10.5 & 0.1 & 0.13 & 57 \\
\hline
\end{tabular}

* In the $0.5 \mathrm{ml}$. aqueous lysin solution before adding $2.5 \mathrm{ml}$. chloroform + methanol.

\section{Extraction and purification}

The solvent transfer process (see Methods) depends on the fact that in the chloroform + methanol + water (10:5:3, by vol.) system the distribution of the lysin was strongly in favour of the top phase under acid conditions and slightly in favour of the lower phase at neutrality. Thus the lysin could be transferred from lower into top phase or vice versa by appropriate addition or neutralization of acid. The results of a series of attempts to measure the partition coefficient under different conditions are given in Table 2. Predictably, the presence of electrolyte lowered the partition coefficient and single observations show it lower at $\mathrm{pH}{ }_{10.5}$ than at $\mathrm{pH} 7$. Distributions carried out at $0^{\circ}$ gave similar values to those obtained at room temperature. In preparative work, where the concentration of lysin was 
higher and the surface/volume ratios lower, the partition coefficient in acid was higher and recovery better than given in Table 2. Sometimes repeated extractions of a neutral top phase with small volumes of fresh lower phase gave a progressively increasing partition coefficient indicating the presence of a small amount of an active material staying mainly in the top phase; this was confirmed using an eight-tube and a six-tube counter-current distribution.

\section{Properties}

The purified material (see Methods) was a friable, off-white chalky solid apparently containing 5 to $15 \%$ of moisture removable over $\mathrm{P}_{2} \mathrm{O}_{5}$. The observations below were made on such material which had not been exhaustively dried, though quantitative results are given in terms of dry material.

Activity. The best preparations contained 250 to $300 \mathrm{HU} / \mathrm{mg}$.

Solubility. The material was insoluble in chloroform, acetone or hexane, sparingly soluble in methanol and very soluble in chloroform + methanol $(2: \mathrm{I}, \mathrm{v} / \mathrm{v})$, saline and water, though the rate of solution in water and saline was slow. (Yoshida (I963) had found that crude lysin was soluble in chloroform + methanol), $2: \mathrm{I}, \mathrm{v} / \mathrm{v}$ ) but that his crystalline product was not; he used chromatography in organic solvents on silicic acid as a purification step.)

Freshly prepared lysin gave a completely clear solution in water as did a dried preparation containing about $12 \%$ moisture which had been stored at $4^{\circ}$ for 4 months; however, the same preparation stored at $4^{\circ}$ over $\mathrm{P}_{2} \mathrm{O}_{5}$ acquired an insoluble skin which interfered with solution, but it eventually dissolved to give a suspension of fine filmy fragments which could be spun down, leaving a supernatant solution with scarcely diminished activity. The thoroughly washed fragments were soluble in dilute alkali and had an activity of about I $70 \mathrm{HU} / \mathrm{mg}$.

Attempts to crystallize the lysin from aqueous or organic solvents have so far failed.

Stability. As mentioned, lysin appeared to be rapidly adsorbed to, and destroyed on, glass and other solid surfaces; however, it was only slowly inactivated at gas/water interfaces, as, for example, during passage of fine bubbles through a solution, or 'tumbling' in a closed vessel. (Plommet \& Bouillanne (1966) prepared delta- and gamma-lysin in a wellstirred culture aerated through a sparger.) At $100^{\circ}$ and $\mathrm{pH} 7$ the half life was about 5 min.; little or no activity was lost in either $\mathrm{M}-\mathrm{HCl}$ or $0 . \mathrm{I} \mathrm{M}-\mathrm{NaOH}$ at $37^{\circ}$ in $\mathrm{I} \mathrm{h}$.; it was stable in chloroform + methanol $(2: \mathrm{I}, \mathrm{v} / \mathrm{v})$ (with or without water) and could be refluxed in this solvent for $4.5 \mathrm{~h}$. without detectable loss.

General properties. The lysin was not dialysable through cellophane either in neutral or alkaline aqueous solutions or in the acid top phase of the chloroform + methanol + water system. It was completely precipitated by $50 \%\left(\mathrm{NH}_{4}\right)_{2} \mathrm{SO}_{4}$. It was surface active, as shown by a marked change in contact angle within less than I min. when lysin, to a final concentration of 3 to $4 \mathrm{HU} / \mathrm{ml}$, was added to a drop of water on a water-repellent surface. It was destroyed by crystalline pepsin, crystalline trypsin, and Nagarse enzyme, but not by the venom of Crotalus adamanteus, nor was it inactivated by $8 \mathrm{M}$-urea, mercaptoethanol, cysteine, $p$-chloromercuribenzoate or sodium methoxide.

No precipitate or colour change occurred on mixing with dilute $\mathrm{Fe}^{3+}, \mathrm{Zn}^{2+}, \mathrm{Cu}^{2+}, \mathrm{Co}^{2+}$, $\mathrm{Hg}^{2+}$ or $\mathrm{Ba}^{2+}$ salts, but with lead acetate a faint haziness developed. Gelatinous or fibrous precipitates formed with phosphomolybdic, trichloroacetic, and phosphotungstic acids.

Phosphorus, carbohydrate, and fatty acid content. The phosphorus content (Chen, Toribara \& Warner, 1956) was $0.27 \%$. With the anhydrone reagent, a carbohydrate equivalent to $\mathrm{I} \cdot 7 \%(\mathrm{w} / \mathrm{w})$ glucose was found, but by gas-liquid chromatography (g.l.c.) of silylated carbo- 
hydrates only two small peaks were seen, of uncertain identity, and equivalent to less than $0.2 \%$ glucose. The fatty acid content was insignificant (less than I \% using $4.8 \mathrm{mg}$. lysin) as determined after saponification in $10 \%$ methanolic $\mathrm{KOH}$ and g.l.c. of the isolated acids.

Gel-filtration experiments. In $0 \cdot \mathrm{I} \mathrm{M}-\mathrm{NaCl}$ the lysin was completely excluded from Sepha$\operatorname{dex}$ G-50; on Sephadex G-I00 and G-200 the $K_{\mathrm{d}}$ values were 0.18 and 0.30 respectively. There were in all cases single peaks of activity which emerged very slightly behind the single peak of absorption at $280 \mathrm{~nm}$.

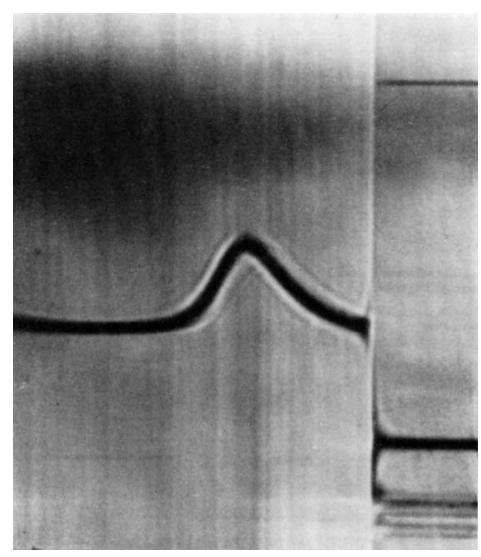

Fig. 2. Schlieren pattern of lysin, $6.0 \mathrm{mg}$. $/ \mathrm{ml}$. in $0 \cdot 1$ M-sodium chloride. Photograph taken after 40 min. at $59,780 \mathrm{rev} . / \mathrm{min}$. in a Beckman, model E, analytical centrifuge. Schlieren angle $65^{\circ}$. $S_{20, \mathrm{w}}=4.9 \times 10^{-13} \mathrm{~s}$.

Ultraviolet extinction. At $280 \mathrm{~nm} . E_{1 \mathrm{~cm} .}^{0.1 \%}=\mathrm{I} \cdot \mathrm{I}$. There was a small shoulder at $290 \mathrm{~nm}$. having $E_{1 \mathrm{~cm} .}^{0.1 \%}=0.87$.

Amino acid composition. From $\mathrm{I} \cdot 29 \mathrm{mg}$. of lysin the following amounts ( $\mu \mathrm{mol}$.) of amino acids were found: lysine, $\mathrm{I} \cdot 22 \mathrm{I}$; aspartic acid, 0.976 ; threonine, 0.668 ; serine, 0.285 ; glutamic acid, 0.464 ; glycine, 0.727 ; alanine, 0.529 ; valine, 0.492 ; methionine, 0.385 ; isoleucine, 0.940 ; leucine, 0.568; phenylalanine, 0.685; ammonia, 0.663 ; tyrosine, arginine, proline and cystine, absent; histidine, or possibly a methyl histidine, a trace. Total weight of amino acids recovered, $0.877 \mathrm{mg}$. $(68 \cdot 0 \%)$.

Tryptophan is, of course, destroyed during the acid hydrolysis but from the high extinction at $280 \mathrm{~nm}$. and because of the absence of tyrosine, lysin probably contains about $4 \%$ tryptophan. Attempts at direct determination of tryptophan have, so far, failed; the method of Gaitonde \& Dovey (1970) gave inconsistent results and the alkaline hydrolysis method of Noltman, Mahowald \& Kuby (1962) could not be carried out satisfactorily with the glass tubing available.

Behaviour in the ultracentrifuge. A sedimentation coefficient, $S_{20, \mathrm{w}}=4.9 \times 10^{-13} \mathrm{~s}$, was calculated after ultracentrifuging (Fig. 2). The spread and asymmetry of the single peak suggest polydispersity; comparison with the schlieren pattern of Yoshida's (I963) material indicate his to be slightly less disperse.

Titration curve. There was no evidence of acid or basic groups disappearing or being unmasked during titration (Fig. 3) and the total lytic activity was unchanged at the end of the titration. Buffering occurred mainly below $\mathrm{pH} 5$ and above $\mathrm{pH} 9$; between $\mathrm{pH} 2.5$ and $7 \cdot 0$ the total buffering power was about $\mathrm{I} \cdot 23$ mequiv., and between $\mathrm{pH} 7$ and 10.5 about 
0.64 mequiv./g. lysin. That the forward and reverse curves do not coincide is presumably due to experimental error.

\section{Electrophoresis}

A. In agar, on slides. Preparations migrated towards the anode in veronal acetate buffer, $\mathrm{pH} 8.6$, in a streak, often most prominent at the origin. Though useless for assessing the purity of delta-lysin, this agar slide method enabled small amounts of contaminating betalysin to be detected (Gladstone \& Yoshida, 1967) and confirmed its absence from preparations studied here.

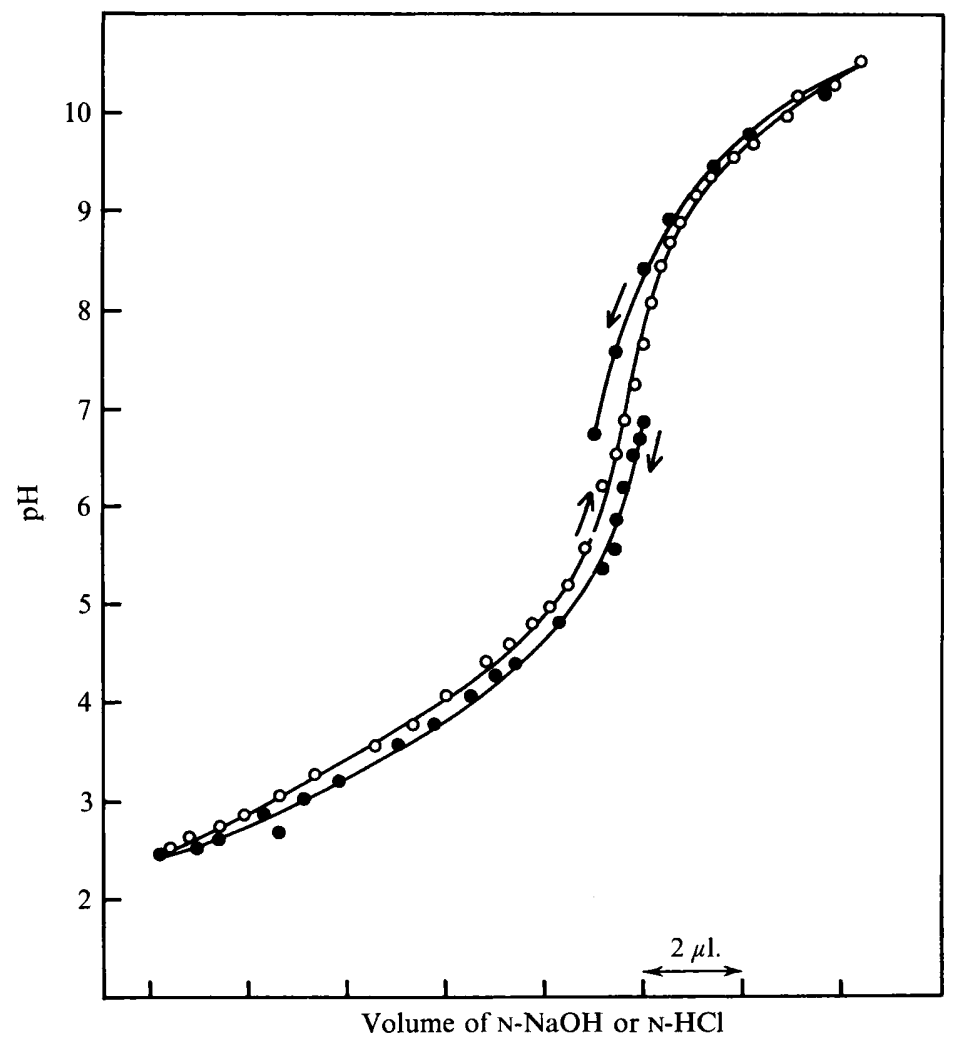

Fig. 3. Titration curve of $7.77 \mathrm{mg}$. lysin in initial volume of $2.0 \mathrm{ml} .0 .1 \mathrm{M}-\mathrm{NaCl}$, corrected for blank titration of $0.1 \mathrm{M}-\mathrm{NaCl}$.

B. In polyacrylamide gels. At $\mathrm{pH} 4 \cdot 6$, with $6 \mathrm{M}$-urea, and at $\mathrm{pH} 8 \cdot 4$, with and without urea, a diffuse main band with a faint diffuse second band were noted. At the lower $\mathrm{pH}$, lysin moved towards the cathode and at the alkaline $\mathrm{pH}$ towards the anode.

Action on phosphatidylinositol. No evidence could be found for the hydrolysis of phosphatidylinositol by lysin, as proposed by Wiseman \& Caird (I968), although their procedure was followed as closely as possible; furthermore, no diglyceride liberated from phosphatidylinositol was detected by a sensitive thin-layer chromatography (t.l.c.) method. 


\section{DISCUSSION}

It is striking that a protein sufficiently large to be totally excluded from Sephadex G-50 should be freely soluble and stable in chloroform + methanol, even after refluxing for some hours; and further, that in the system chloroform + methanol + water (I0:5:3, by vol.) the protein should distribute mainly in the upper or in the lower phase according to whether the system is acid or neutral. Such behaviour might conceivably occur with other proteins which are both acid-stable and unaffected by chloroform + methanol. Such phase transfer, when applicable, is usually a powerful purification procedure and it is disappointing that the final lysin preparation should be polydisperse in the ultracentrifuge and should give a faint diffuse second band on polyacrylamide gel electrophoresis. For these reasons, the amino acid composition and other quantitative observations should be treated with reserve, though the absence of arginine, tyrosine, proline, cysteic acid and cystine must be a genuine property of the pure lysin. The absence of arginine is interesting since it was the only amino acid universally present in eighty different proteins whose composition was studied by Smith (1966). The relation between the titration curve and the amino acid composition is reasonably good; from the latter the amount of lysin used for the titration curve would contain $7.36 \mu \mathrm{mol}$. of lysine and $8.68 \mu \mathrm{mol}$. of aspartic + glutamic acids. From the titration curve it will be seen that to bring the $\mathrm{pH}$ from 5.0 to 2.5 required $8.0 \mu$ equiv. of acid, and from $\mathrm{pH} 9.0$ to 10.5 (when perhaps roughly half of the lysine might have been titrated) required $3.5 \mu$ equiv. of alkali. The absence of fatty acids must also be significant, and possibly the low content of phosphorus and carbohydrate. More precise analysis must await further purification.

The adsorption of lysin to glass, which can mimic spontaneous loss of activity, enzymic destruction, etc., must be borne in mind in interpreting results; dilute tetanus toxin behaves similarly, and some of the misleading conclusions resulting therefrom over the years have been listed by Pound (1970).

After completion of most of this work a manuscript copy of a paper (Kreger et al. I97I) on delta-lysin was courteously sent by Dr Kreger. My own work agrees in most respects with their much fuller report, but the relationship of my solvent-extracted material to their two soluble forms or to the delta-lysins described by others has yet to be established. Some of the conflicting reports in the literature on solubility, stability, etc., may be explainable in terms of multiplicity of lysins, and it will be essential in future to know which lysin or form of lysin is being studied.

I am indebted to Dr G. P. Gladstone for helpful discussions, to Mr A. Nurden for the gas chromatographic determinations of carbohydrate and fatty acid, to $\mathrm{Mr} \mathrm{N}$. Rníc for the amino acid analysis, and to Dr A. Rodgers for the ultracentrifuge examination. For valuable technical assistance at different times, I am grateful to Miss D. Wingrove, Miss M. Bergin and Mrs P. Payne.

\section{REFERENCES}

Chen, P. S., Jun., Toribara, T.Y. \& Warner, H. (1956). Microdetermination of phosphorus. Analytical Chemistry 28, 1756-1 758.

Chrambach, A., Reisfeld, R. A., Wyckoff, M. \& Zacchari, J. (I967). A procedure for rapid and sensitive staining of protein fractionated by polyacrylamide gel electrophoresis. Analytical Biochemistry 20, I50-154.

Folch, J., Lees, M. \& Sloane-Stanley, G. H. (1957). A simple method for the isolation and purification of total lipides from animal tissues. Journal of Biological Chemistry 226, 497-509. 
GaitonDE, M. K. \& Dovey, T. (1970). A rapid and direct method for the quantitative determination of tryptophan in the intact protein. Biochemical Journal II7, 907-9 I I.

Gladstone, G. P. \& van HeYningen, W. E. (1957). Staphylococcal leucocidins. British Journal of Experimental Pathology 38, I23-137.

GLADSTONE, G. P. \& YoshidA, A. (1967). The cytopathic action of purified staphylococcal $\delta$-haemolysin. British Journal of Experimental Pathology 48, I I-19.

HALlANDER, H. O. (1968). Characterization and partial purification of staphylococcal delta-lysin. Acta pathologica et microbiologica scandinavica 73, 586-700.

van Heyningen, W. E. \& Gladstone, G. P. (1953). The neurotoxin of Shigella shigae. 3. The effect of iron on production of the toxin. British Journal of Experimental Pathology 34, 22 I-229.

KAYSER, A. \& RAYNAUd, M. (1965) Étude d'une hémolysine (distincte de l'hémolysine $\alpha$ ) présente dans les filtrats de culture de la souche Wood 46 de Staphylococcus aureus (hémolysine G ou $\delta$ ). Annales de l'Institut Pasteur 108, 215-233.

Kreger, A. S., Kim, K-S., Zaboretzky, F. \& Bernheimer, A. W. (I97I). Purification and properties of staphylococcal delta haemolysin. Journal of Bacteriology. (In Press.)

Morgan, J. F., Morton, H. J. \& PARKer, R. C. (1950). Nutrition of animal cells in tissue culture. I. Initial studies on a synthetic medium. Procecdings of the Society of Experimental Biology and Medicine, New York 73, I-8.

Noltman, E. A., Mahowald, T. A. \& Kuby, S. A. (1962). Studies on adenosine triphosphate transphosphorylases. Journal of Biological Chemistry 237, I I46-I I 54.

Plommet, M. \& Bouillanne, C. (1966). Production des hémolysines staphylococciques delta et gamma. Annales de biologie animale, biochimie et biophysique 6, 529-532.

Pound, A. W. (1970). The influence of certain lipids and proteins on the effect of tetanus toxin in mice. Journal of Medical Microbiology 3, 41 I-426.

Sмiтн, M. H. (1966). The amino acid composition of proteins. Journal of Theoretical Biology 13, 261-282.

WiLliams, R. E. O. \& HARPER, G. J. (1947). Staphylococcal haemolysins on sheep-blood agar with evidence for a fourth haemolysin. Journal of Pathology and Bacteriology 59, 69-78.

WisemAN, G. M. (1970). Beta and delta toxins of Staphylococcus aureus. In Microbial Toxins, vol. III, pp. 253263. Edited by T. C. Montie, S. Kadis \& S. J. Ajl. New York: Academic Press.

Wiseman, G. M. \& CaIRD, J. D. (1968). Phospholipase activity of the delta hemolysin of Staphylococcus aureus. Proceedings of the Society of Experimental Biology and Medicine, New York 128, 428-430.

YoshIDA, A. (1963). Staphylococcal $\delta$-hemolysin. I. Purification and chemical properties. Biochimica et biophysica acta 7r, 544-553. 